\title{
Evidence for Metalloproteinase and Metalloproteinase Inhibitor Imbalance in Human Osteoarthritic Cartilage
}

David D. Dean, Johanne Martel-Pelletier,“ Jean-Pierre Pelletier,“ David S. Howell, and J. Frederick Woessner, Jr. Departments of Biochemistry \& Molecular Biology and Medicine, University of Miami School of Medicine, Miami, Florida 33101; Research Service, Veterans Administration Medical Center, Miami, Florida 33125; and *Department of Medicine,

University of Montreal School of Medicine, Notre Dame Hospital, Montreal, Quebec, Canada H2L 4 K8

\section{Abstract}

Cartilage specimens from tibial plateaus, obtained from 13 osteoarthritic (OA) patients and seven controls, were selected from three regions: zone $A$, center of fibrillated area; zone $B$, area adjacent to fibrillation, and zone $C$, remote region of plateau. Acid and neutral metalloproteinases and tissue inhibitor of metalloproteinase (TIMP) were extracted with 2 M guanidine. Methods were developed to selectively destroy either proteinases or TIMP to prevent cross-reaction during assay. Acid and neutral proteinases were elevated $~ 150 \%$ in OA; TIMP was elevated $\sim 50 \%$. A positive correlation $(r=0.50)$ was found between acid and neutral proteinase activities in OA, but not in controls. Both proteinases were elevated two- to threefold in zones $A, B$, and $C$. However, the self-active form of the acid metalloproteinase was elevated only in zones $A$ and $B$ (200\%); it correlated well with the Mankin scores, whereas the total activities did not. TIMP was elevated (50\%) only in zones $A$ and B. Both the proteinase levels and the Mankin score were elevated to a greater extent in the medial, than in the lateral, compartment. Titration of TIMP against the two metalloproteinases indicates that there is a small excess of inhibitor over enzymes in normal cartilage. In OA, TIMP does not increase to the same extent as the proteinases; the resultant excess of proteinases over TIMP may contribute to cartilage breakdown.

\section{Introduction}

Osteoarthritis $(\mathrm{OA})^{1}$ is characterized by loss of matrix proteoglycans, fibrillation of the cartilage surface, and eventual loss of collagenous matrix to expose the underlying bone (1). At least three factors contribute to joint matrix destruction (2): (a) mechanical wear, $(b)$ failure of the chondrocyte to maintain a balance of matrix synthesis and degradation, and (c) extracartilaginous factors such as bony remodeling and synoviummediated events.

Mankin et al. (3) and Ehrlich (4) found a consistent loss of matrix proteoglycans in cultured OA cartilage. Sapolsky et al.

Address reprint requests to Dr. Woessner, Department of Biochemistry \& Molecular Biology (R-127), University of Miami School of Medicine, P.O. Box 016960, Miami, FL 33101.

Received for publication 18 May 1988 and in revised form 29 March 1989.

1. Abbreviations used in this paper: APMA, aminophenylmercuric acetate; OA, osteoarthritis; TIMP, tissue inhibitor of metalloproteinases.

\section{J. Clin. Invest.}

(C) The American Society for Clinical Investigation, Inc.

0021-9738/89/08/0678/08 \$2.00

Volume 84, August 1989, 678-685
(5) showed that OA cartilage contained elevated levels of cathepsin D. However, because the $\mathrm{pH}$ optimum of cathepsin D on proteoglycan lies between 4 and 4.5 , it is unlikely to play an important role in the extracellular matrix, where the $\mathrm{pH}$ is $\sim$ 7.2. Human articular cartilage also contains metalloproteinases that can degrade collagen and proteoglycan at physiological pH (6). We have isolated and characterized two metalloproteinases that digest proteoglycan $(7,8)$. Both a neutral and an acid metalloproteinase are found; the acid enzyme has significant activity at $\mathrm{pH} 7$. Both proteinases are elevated in OA cartilage of the tibial plateau $(9,10)$, as is collagenase $(11,12)$.

Human cartilage also contains a tissue inhibitor of metalloproteinases or TIMP $(13,14)$, which inhibits all three proteinases. TIMP was not elevated in OA patellar cartilage (8, 14), whereas the proteinases were elevated about threefold. This may lead to an imbalance in OA so that the proteinases escape control by the inhibitor and produce excessive matrix degradation.

Our previous measurements of metalloproteinases in tibial plateau cartilage were based on assays of homogenates in which the endogenous collagen or proteoglycan served as substrate. We now report new methods for the extraction of the proteinases and their assay on exogenous, standardized substrates. While this extraction yields twice as much activity as detected by previous assays of homogenates, it is possible that unextracted enzyme activity still remains in the tissue. We have also found selective methods to destroy either the proteinases or the TIMP so that each can be measured directly in the extracts without prior separation and without interference with the other measurements. These methods have been applied to normal and OA cartilage specimens to explore early stages of $\mathrm{OA}$ and to compare changes in lateral and medial compartments of the tibial plateau. The results add strong support to our earlier hypothesis (14) that the increase in proteinase activity in OA leads to an imbalance of enzyme over inhibitor that may be important in the progression of the disease.

\section{Methods}

Patient selection and tissue preparation. Patients undergoing joint arthroplasty were selected with the goal of studying OA of mild to moderate severity. Of the 30 patients screened at the Department of Orthopaedic Surgery, St. Luc and Notre-Dame Hospitals, University of Montreal School of Medicine, only 13 met this criterion. Cartilage was taken from only one of the two tibiofemoral compartments because cases with moderate medial compartment disease had virtually no lesions in the lateral compartment and those with mild to moderate lateral compartment disease had too little cartilage for sampling in the medial compartment.

At the time of resection, each tibial plateau was removed, rinsed with cold saline, and chilled on ice in a Dewar flask in the operating 
room. It was carried to the lab and tested for carbon black retention (15). Blocks of tissue $\left(0.25 \mathrm{~cm}^{2}\right)$, extending into the subchondral bone, were then excised from 3 sites as previously described (11). Site A included the center of the fibrillated or eroded lesions (usually in the weight-bearing area), site B samples were from the margin of the lesion, and site $\mathrm{C}$ samples were collected 1 or more $\mathrm{cm}$ away from the lesion in site A (Fig. 1). It was not always possible to obtain three blocks from each specimen. A small section of each block was used for histological-histochemical grading according to Mankin et al. (3). The remainder $(75-100 \mathrm{mg}$ ) was separated from the underlying bone and frozen at $-70^{\circ} \mathrm{C}$ in physiological saline until analyzed.

Fresh control tissues were obtained postmortem from seven subjects and tested for carbon black retention as above. Samples of tibial plateau cartilage were obtained from sites corresponding to those resected from the osteoarthritic knees and then frozen in physiological saline as described above. Histological grading was not performed, since a large number $(n>60)$ of such samples in earlier studies, were found to have an average Mankin score of 0-1 (11).

Extraction of TIMP and metalloproteinases. Preliminary extraction methods were developed using human patellar cartilage from autopsies. Several OA specimens from tibial plateaus, obtained from Dr. Jerry Enis in Miami at arthroplasty, were used to confirm that the extraction methods were suitable for surgical specimens. Sterile technique was used insofar as practicable. All buffer solutions and glassware were autoclaved before use and instruments were soaked in $70 \%$ ethanol.

Each cartilage block was minced and homogenized in a 12-ml polyallomer centrifuge tube in various extraction buffers (e.g., $50 \mathrm{mM}$ Tris- $\mathrm{HCl}, 10 \mathrm{mM}$ calcium chloride, $2 \mathrm{M}$ guanidine hydrochloride, $\mathrm{pH}$ 7.5) with a Polytron device (Brinkmann Instruments Co., Inc., Westbury, NY) using a PT-10 ST saw tooth generator at $4^{\circ} \mathrm{C}$ (7). The homogenate was centrifuged at $21,000 \mathrm{~g}$ for $30 \mathrm{~min}$ at $4^{\circ} \mathrm{C}$. The supernatant was dialyzed into assay buffer $(50 \mathrm{mM}$ Tris- $\mathrm{HCl}, 10 \mathrm{mM}$ calcium chloride, $0.2 \mathrm{M}$ sodium chloride, $0.05 \%$ Brij $35,0.02 \%$ sodium azide, pH 7.5) using 14,000 $\mathrm{M}_{\mathrm{r}}$ cut-off Visking dialysis tubing (Union Carbide, Danbury, CT). Streaks of pellets and extracts on Lennox agar plates were incubated for $24 \mathrm{~h}$ to test for microbial contamination. The dialyzed crude extracts were used directly for assay of protein and proteoglycan or treated as described below before assay of metalloproteinases and TIMP.

The following optimized methods were adopted for routine assays. Cartilage specimens were thawed at $24^{\circ} \mathrm{C}$, blotted and weighed (there was $<10 \%$ change in weight upon freezing). The specimens were diced and 4-8 $\mathrm{mg}$ were weighed for DNA assay (see below). The remaining

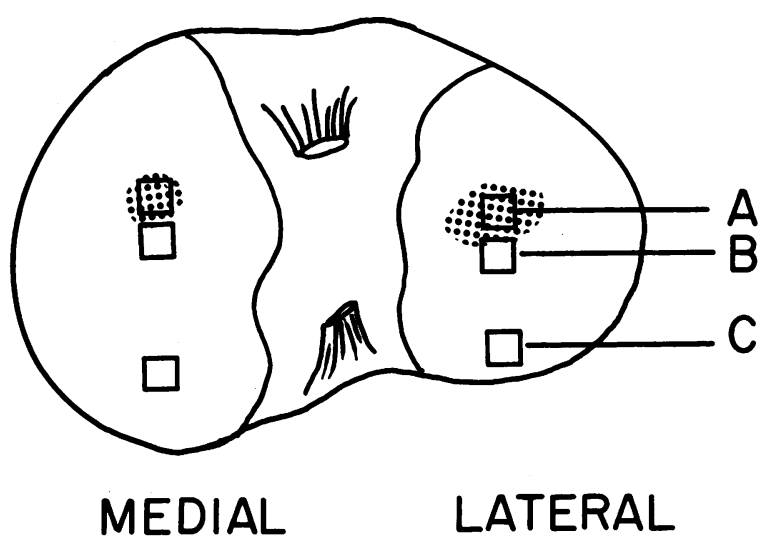

Figure 1. Schematic representation of a human tibial plateau showing the sites where samples were obtained. In OA samples, site A was in the center of fibrillated tissue; site $B$ was an area adjacent to site $A$; and site $C$ was remote from the lesion and at least $1 \mathrm{~cm}$ from site A. Control samples were collected from sites corresponding to those found in OA. tissue was homogenized in $40 \mathrm{vol}(100 \mathrm{mg}$ of tissue per $4 \mathrm{ml}$ of extraction buffer) $50 \mathrm{mM}$ Tris- $\mathrm{HCl}, 10 \mathrm{mM}$ calcium chloride, $2 \mathrm{M}$ guanidine- $\mathrm{HCl}, \mathrm{pH} 7.5$, buffer at $4^{\circ} \mathrm{C}$ and dialyzed as described above for the patellar samples.

Metalloproteinase assays. The tritiated proteoglycan bead assay of Nagase and Woessner (16) as modified by Azzo and Woessner (8) was used. Proteoglycan monomer was purified from bovine nasal septum cartilage and labeled with $\left[{ }^{3} \mathrm{H}\right]$ acetic anhydride (7). The labeled proteoglycan monomer $(80,000 \mathrm{cpm} / \mathrm{mg})$ was entrapped in polyacrylamide gel beads having a pore size that retains the monomers but permits the escape of digestion products smaller than $\sim 200,000$ daltons. The assay gave a linear response with $0.3-3.0 \mathrm{ng}$ of trypsin over a 4-h period at $37^{\circ} \mathrm{C}$ with a reproducibility of $\pm 8 \%$.

Neutral and acid metalloproteinase activities were determined after selective destruction of TIMP by reduction and alkylation $(13,17)$. This treatment had no effect on the metalloproteinases and destroyed TIMP before it could complex with the proteinases in the crude extracts (see Results). The crude extracts were incubated at $37^{\circ} \mathrm{C}$ for 30 min with $2 \mathrm{mM}$ dithiothreitol. Iodoacetamide $(5 \mathrm{mM})$ was added for an additional $30 \mathrm{~min}$ at $37^{\circ} \mathrm{C}$. The reagents were removed by overnight dialysis against assay buffer at $4^{\circ} \mathrm{C}$. The possible presence of another inhibitor, $\alpha_{2}$-macroglobulin, was ruled out by treatment of the crude extracts with $3.0 \mathrm{M}$ potassium thiocyanate (18).

For proteinase assay, $0.1-\mathrm{ml}$ enzyme samples were mixed with 0.1

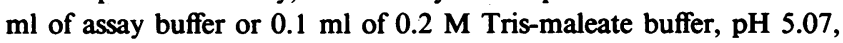
containing $10 \mathrm{mM}$ calcium chloride. Addition of this second buffer gave a final $\mathrm{pH}$ of 5.3 at $37^{\circ} \mathrm{C} .1 \mu \mathrm{g}$ of pepstatin was added to inhibit cathepsin D. Aminophenylmercuric acetate (APMA, practical, ICN Biochemicals, Irvine, $\mathrm{CA}$ ) was added at $1 \mathrm{mM}$ to activate latent enzyme. Blanks contained $1 \mathrm{mM}$ 1,10-phenanthroline (Sigma Chemical Co., St. Louis, MO) to inhibit metalloproteinase activity.

The incubation was conducted in 7.0-ml scintillation vials containing $\sim 2 \mathrm{mg}$ of $\left[{ }^{3} \mathrm{H}\right]$ proteoglycan beads $(12,000 \mathrm{cpm} / \mathrm{mg}$ beads, 150 $\mu \mathrm{g}$ proteoglycan/mg beads). The enzyme-buffer mixture $(200 \mu \mathrm{l})$ was added to the vial and incubated for $18 \mathrm{~h}$ at $37^{\circ} \mathrm{C}$. At the end of the incubation, $6.0 \mathrm{ml}$ of Aquasol scintillation fluid (New England Nuclear, Boston, MA) was added and the vials counted at room temperature in a scintillation counter (Tri-Carb model 3003, Packard Instrument Co., Inc., Downers Grove, IL) at 58\% efficiency. Enzyme activity was expressed as counts per minute of tritium released per $\mathrm{mg}$ proteoglycan beads or calculated as units per gram of wet weight tissue. One enzyme unit was equivalent to $1 \mu \mathrm{g}$ of $\left[{ }^{3} \mathrm{H}\right]$ proteoglycan released per minute at $37^{\circ} \mathrm{C}$ from $2 \mathrm{mg}$ of beads.

TIMP assay. TIMP was assayed with a low $M_{\mathrm{r}}$ metalloproteinase isolated from rat uteri at $1 \mathrm{~d}$ postpartum as previously described (13, 19) with slight modification. The enzyme was partially purified by chromatography on Ultrogel AcA 54 (LKB Instruments, Inc., Rockville, MD). The enzyme peak from the gel filtration column was then applied to a 1.5-ml column of Blue Sepharose CL-6B (Pharmacia, Inc., Piscataway, NJ) in assay buffer and eluted with a $0.2-2.0 \mathrm{M}$ sodium chloride gradient. The enzyme was activated with $0.5 \mathrm{mM}$ APMA for 1 $h$ at $37^{\circ} \mathrm{C}$ and then dialyzed free of APMA.

TIMP activity in the crude extracts was determined after selective destruction of the metalloproteinases. The method is based on the principle that the metalloproteinases become heat-labile in the absence of their intrinsic $\left(\mathrm{Zn}^{+2}\right)$ and extrinsic $\left(\mathrm{Ca}^{+2}\right)$ divalent cations. TIMP, on the other hand, is stable at temperatures that destroy the destabilized metalloproteinases (13). EDTA was added to the dialyzed crude extracts at a final concentration of $40 \mathrm{mM}$ from a stock solution of 50 $\mathrm{mM}$ Tris- $\mathrm{HCl}, 200 \mathrm{mM}$ EDTA, $\mathrm{pH} \mathrm{7.5}$, and allowed to stand at $24^{\circ} \mathrm{C}$ for $30 \mathrm{~min}$. The samples were next placed in a $60^{\circ} \mathrm{C}$ water bath for $1 \mathrm{~h}$ and then dialyzed against assay buffer in standard Visking tubing for 2 d at $4^{\circ} \mathrm{C}(10$-ml samples vs. four changes of 4 liters).

Active uterine metalloproteinase (10-30 $\mu$ l, 0.28 enzyme units), inhibitor $(0-200 \mu \mathrm{l})$, and assay buffer were preincubated for $1 \mathrm{~h}$ at $37^{\circ} \mathrm{C}$ in a total volume of $300 \mu \mathrm{l}$. The assay was then conducted by adding $950 \mu \mathrm{l}$ of assay buffer containing $1 \mathrm{mg}$ Azocoll (CalbiochemBehring Corp., San Diego, CA) and incubated for $18 \mathrm{~h}$ at $37^{\circ} \mathrm{C}$ with 
horizontal shaking; $1 \mathrm{mM}$ 1,10-phenanthroline was added to provide blanks. After incubation, the absorbancy of the supernatant was read at $520 \mathrm{~nm}$. One unit of inhibitor blocks one unit of enzyme activity (one enzyme unit $=1 \mu \mathrm{g}$ of Azocoll digested per minute at $37^{\circ} \mathrm{C}$ ).

Assay of DNA, protein, and proteoglycan. Cartilage samples (4-8 $\mathrm{mg}$ wet weight) were digested according to the method of Oegema et al. (20) in $200 \mu \mathrm{l}$ of $0.1 \mathrm{M}$ sodium phosphate buffer, $\mathrm{pH} 6.5$, containing $0.01 \mathrm{M}$ EDTA and $100 \mu \mathrm{g}$ of proteinase $\mathrm{K}$ (type XI from Tritirachium album, Sigma Chemical Co.). After $18 \mathrm{~h}$ at $56^{\circ} \mathrm{C}$, the digests were cooled and frozen at $-20^{\circ} \mathrm{C}$ until assayed. The DNA content in $10-20-\mu 1$ aliquots of the digests was determined by the method of LaBarca and Paigen (21). A standard curve was prepared from highly polymerized calf thymus DNA (type I, $E_{260}$ for $1 \mu \mathrm{g}=0.0246$; Sigma Chemical Co.). Protein in the crude extracts was measured by the Bradford method (22). Proteoglycan was measured in the same extracts with the metachromatic dye 1,9-dimethylmethylene blue (23) and compared to a standard of chondroitin sulfate (Sigma Chemical Co.).

Statistical analyses. All experimental samples were processed without knowledge of disease or its severity. Samples were supplied with a numerical code and processed at random. At the end of the study, samples were identified and data for sites A-C were grouped together for each patient. Differences between groups were determined by analysis of variance and the Tukey test (24); in cases of single comparisons Student's $t$ test was used. Linear correlation analysis was performed according to Zar (24).

\section{Results}

Extraction of metalloproteinases and TIMP from cartilage. Before clinical specimens could be studied, it was necessary to develop methods for the quantitative extraction of the proteinases and TIMP, to find ways to measure each component in the presence of the others, and to validate the final assay methods. Postmortem patellae provided sufficient tissue for development of these methods. This tissue was dispersed in different solutions using a Polytron homogenizer (see Methods). Various combinations of Tris with $0.1 \%$ Triton $\mathrm{X}-100$ and $\mathrm{CaCl}_{2}$ were tried, together with various heating
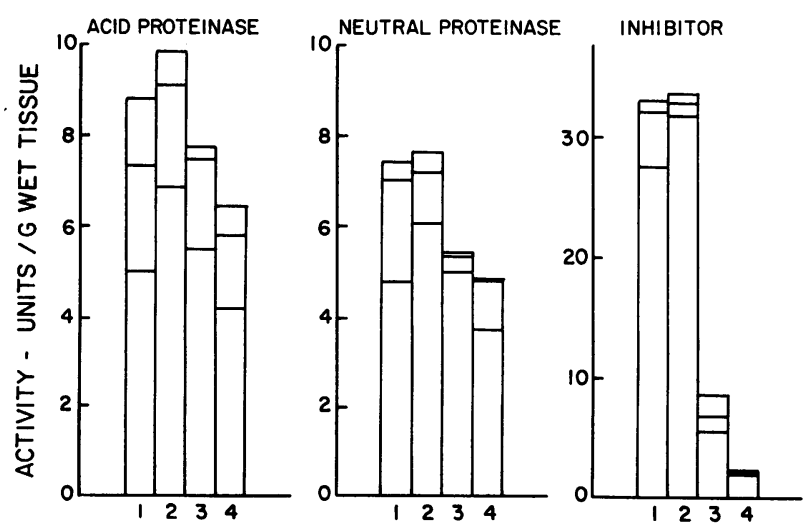

GUANIDINE HCl - MOLARITY

Figure 2. Extraction of metalloproteinases and TIMP from human osteoarthritic articular cartilage with varying concentrations of guanidine-HCl. Human patellar cartilage was extracted with $1,2,3$, or 4 $M$ buffered guanidine as described in the Methods section. Cartilage was homogenized in $20 \mathrm{vol}$ of buffer and centrifuged. Three sequential extractions are shown in each bar with the first extraction at the bottom. Total neutral and acid metalloproteinase and TIMP activity were determined as described in Methods.
Table I. Denaturation of Metalloproteases and TIMP

\begin{tabular}{cccc}
\hline & \multicolumn{2}{c}{ Protease } \\
\cline { 2 - 4 } Treatment & Neutral & Acid & TIMP \\
\hline & \multicolumn{3}{c}{ U/g wet tissue } \\
Destroy proteinase & & & \\
Crude extract & 5.14 & 5.80 & 40 \\
Heat with EDTA & 0.48 & 0.57 & 42 \\
Reduce/alkylate* & 0.49 & 0.56 & 0 \\
Destroy inhibitor & & & \\
Crude extract & & & \\
(active form) & 2.85 & 4.27 & 47 \\
Reduce/alkylate & 0.87 & 1.26 & NA \\
(active form) & 3.65 & 5.70 & 0.4 \\
& 1.62 & 2.41 & NA \\
\hline
\end{tabular}

Cartilage was obtained from OA patellas and combined to make a single large extract. Proteinases were assayed with APMA to measure total activity; APMA was omitted to measure "active form." Denaturation of enzyme by EDTA/heat treatment and of TIMP by reduction and alkylation is described in Methods. NA, not applicable.

* Reduction and alkylation were performed after heat treatment with EDTA.

regimens, since such methods were effective for extraction of uterine collagenase (25). However, buffered guanidine- $\mathrm{HCl}$ gave the best extraction (Fig. 2). Two 20-vol extracts in $2 \mathrm{M}$ guanidine- $\mathrm{HCl}$ provided optimal recovery of both proteinases and of TIMP (92-99\% of the amount obtained with 4 extracts). Subsequently, a single 40-vol extraction was found to produce $95-99 \%$ of the recovery obtained with two 20 -vol extractions.

Recovery of enzymes and TIMP was checked by adding back known amounts of active and latent forms of enzymes and of TIMP to previously extracted cartilage pellets. These were then homogenized and the resultant extracts were carried through the assay. It was found that all the added components were recovered with $<10 \%$ loss during homogenization and exposure to guanidine. It was also established that, at $4{ }^{\circ} \mathrm{C}$, active enzyme and TIMP did not combine during the processing.

This extraction protocol gave closely similar results with surgical specimens from the tibial plateau. Such specimens were also frozen without added fluid or in physiological saline at $-70^{\circ} \mathrm{C}$ to ascertain the best method for storage and shipment of specimens from Montreal. Both methods yielded identical results; freezing produced no leakage of proteinase or TIMP into the saline solution, nor was there any decrease in activity compared to fresh, unfrozen tissue.

Selective destruction of metalloproteinases or TIMP. In order to destroy active forms of metalloproteinases that could bind to, and inactivate, TIMP, samples were heated to $60^{\circ} \mathrm{C}$ for $1 \mathrm{~h}$ in the presence of EDTA (Table I). This destroys $90 \%$ or more of both active and latent metalloproteinases. TIMP is completely stable under these conditions. On the other hand, TIMP could interfere with the measurement of active metalloproteinases, especially since incubation lasts $18 \mathrm{~h}$. TIMP could be destroyed by reduction with dithiothreitol followed by alkylation with iodoacetamide (Table I and reference 13). $>99 \%$ of the TIMP is destroyed by this method. It is also seen 
that there is an increase in active enzyme following this treatment, indicating that TIMP had indeed interfered. Activation with APMA requires at least $4 \mathrm{~h}$, so that TIMP is largely destroyed by this reagent before the latent enzyme is activated. But combination with active enzyme can occur before TIMP destruction and enzyme is not recovered by APMA treatment once this has occurred (17).

Extracts were treated with $3 \mathrm{M} \mathrm{KSCN}$ to destroy $\alpha_{2}$-macroglobulin (18). No significant increase in metalloproteinase activity was observed for either normal or osteoarthritic cartilage after such treatment, indicating that this inhibitor was not a significant factor in cartilage.

Validation of the assays. Fig. 3 shows that there is an initial lag of three (acid) to five (neutral) $h$ required for activation of the latent enzymes by APMA; beyond this point, the assays remain linear for at least $18 \mathrm{~h}$. The assay is also linear with respect to amount of enzyme (not shown). Tissue extracts add $\sim 42 \mu \mathrm{g}$ of proteoglycan to the assay. This does not significantly affect the results since the addition of up to $300 \mu \mathrm{g}$ produces $<10 \%$ inhibition. This is due to the fact that most of the fluid in the assay is imbibed by the beads; the enzyme is then largely inside the beads where the added proteoglycan cannot penetrate.

Clinical characteristics of the patient series. As shown in Table II, the 13 patients all had primary OA as based on X-ray grade (26), joint instability consistent with cartilage loss without collateral ligament injury, and other criteria recently established by the American Rheumatism Association (27). If the postoperative assessment based on histological and carbon black scoring did not confirm the diagnosis of primary $\mathrm{OA}$, the patient's tissue was excluded from the study. In the case of control specimens, the medical records were examined to exclude any prior rheumatic disease, including $\mathrm{OA}$.

Changes in proteinases and TIMP in OA. Biochemical results are presented in Table III. The number of assays is two to three times the number of patients owing to sampling three

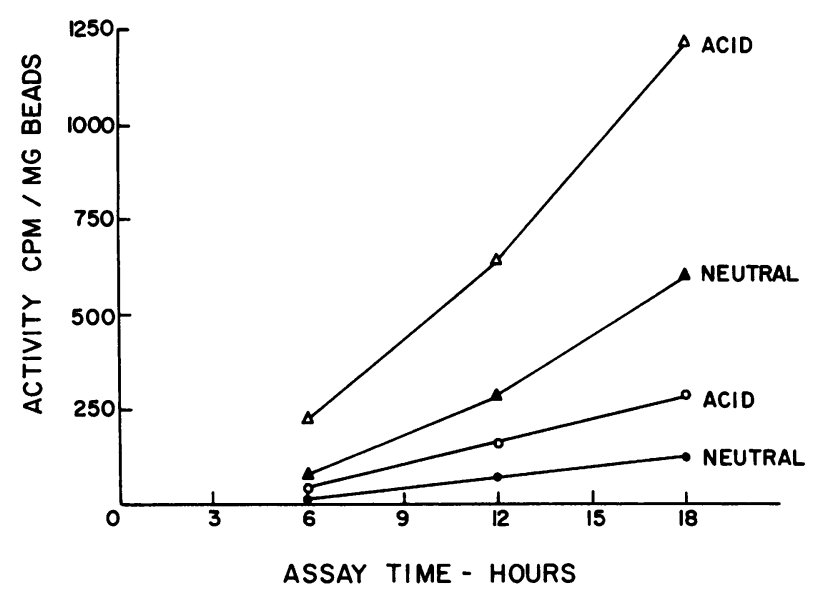

Figure 3. Digestion of tritiated proteoglycan by the extracted metalloproteinase in the bead assay as a function of time. Latent acid or neutral metalloproteinase was assayed in the presence of $1 \mathrm{mM}$ APMA. Activity was expressed as cpm/mg beads above the 1,10 phenanthroline blank; $1,200 \mathrm{cpm} / \mathrm{mg} \mathrm{mg}$ beads was equivalent to $11.4 \%$ digestion and was within the linear range of the assay. ( $\bullet)$ Neutral metalloproteinase from control tissue; ( $\Delta$ ) neutral metalloproteinase from osteoarthritic tissue; ( 0 ) acid metalloproteinase from control tissue; $(\Delta)$ acid metalloproteinase from osteoarthritic tissue.
Table II. Characteristics of Patients and Tibial Plateau Specimens

\begin{tabular}{lccc} 
& & \multicolumn{2}{c}{ Osteoarthritic } \\
\cline { 3 - 4 } \multicolumn{1}{c}{ Parameter } & Control & Lateral & Medial \\
\hline Number & 7 & 7 & 6 \\
Male/female & $5 / 2$ & $3 / 4$ & $1 / 5$ \\
Age (yr) & $51 \pm 7$ & $69 \pm 2$ & $69 \pm 4$ \\
Histology* & $0-1$ & $4.4 \pm 0.4$ & $7.1 \pm 0.5$ \\
Carbon black $^{\ddagger}$ & 0 & $2.7 \pm 0.1$ & $3.5 \pm 0.1$ \\
X-ray grade $^{\S}$ & - & $2.4 \pm 0.1$ & $3.6 \pm 0.2$ \\
\hline
\end{tabular}

* Histological grade as determined by Mankin score (3), based on 19 specimens from the lateral compartment (zones A, B, and C) and 18 from the medial.

¥ Carbon black retention determined according to Meachim (15).

$\$$ X-ray grade determined according to Kellgren and Lawrence (26).

zones of each tibial plateau. The total activity of each metalloproteinase, measured after APMA activation of proenzyme forms, is given first, followed by the amount of active form detected without activation. Thus, the total acid metalloproteinase activity increased $136 \%$ in the OA group compared to controls; the fraction that was active at the time of extraction was increased by $108 \%$. The total neutral proteinase activity increased even more $(160 \%)$, but the active form did not increase significantly. The level of TIMP, on the other hand, increased only 53\%. The total content of DNA in the cartilage did not change significantly. The soluble proteoglycan did not change. It should be noted that no effort was made to extract all proteoglycan, the results reflect only that portion extracted in $2 \mathrm{M}$ guanidine. Linear correlation analyses were performed for the total and active forms of each enzyme against enzyme activity, TIMP levels and Mankin score. Only one positive result was found (Fig. 4); the total acid metalloproteinase activity correlated with the total neutral metalloproteinase in OA with an $r=0.505$ and $P<0.001$.

The samples were then analyzed according to their original location in sites A, B, or C on the tibial plateau (Fig. 5). The control samples showed no significant differences from one region to another, so all results were combined into one group. The total activity of both acid and neutral proteinases was elevated significantly and to a similar extent in all three zones. The active form of the acid enzyme was elevated only in zones A and B; the Mankin scores for zones A, B, and C paralleled the levels of the active proteinase. The inhibitor, TIMP, was elevated to the extent of $50 \%$ and $60 \%$ in zones A and B, but not in $\mathrm{C}$.

The data for samples from medial and lateral compartments are shown in Fig. 6. The controls were pooled since no differences were observed between lateral and medial specimens. As was seen in Table II, the ages of the OA patients in the two groups were not significantly different, but the Mankin scores were different (4.4 vs. 7.1$)$. The total activity of acid proteinase was elevated $53 \%$ in the lateral and $154 \%$ in the medial compartment; the active enzyme was elevated only in the medial compartment. In contrast, the active neutral metalloproteinase was not significantly elevated in either compartment, while the total neutral activity was elevated $203 \%$ in the medial compartment. TIMP was elevated $45-55 \%$ in the two compartments. 
Table III. Proteinase, Inhibitor, and Biochemical Data for All Control and Osteoarthritic Cartilage Samples from Tibial Plateau

\begin{tabular}{|c|c|c|c|c|}
\hline Parameter & Control & Osteoarthritic & Increase & $\neq P$ \\
\hline & & & $\%$ & \\
\hline Acid metalloproteinase* $(U / g$ tissue $)$ & $1.95 \pm 0.20(13)$ & $4.60 \pm 0.45(37)$ & 136 & 0.002 \\
\hline (active form) (U/g tissue $)$ & $0.68 \pm 0.17(13)$ & $1.41 \pm 0.29(28)$ & 108 & NS \\
\hline Neutral metalloproteinase ( $U / g$ tissue) & $0.42 \pm 0.14(16)$ & $1.09 \pm 0.18(37)$ & 160 & 0.05 \\
\hline (active form) $(U / g$ tissue $)$ & $0.20 \pm 0.08(16)$ & $0.21 \pm 0.12(28)$ & 2 & NS \\
\hline Inhibitor (TIMP) (U/g tissue) & $24.7 \pm 3.1(16)$ & $37.8 \pm 3.1(37)$ & 53 & 0.02 \\
\hline DNA ( $\mu g / g$ tissue $)$ & $289 \pm 29(16)$ & $312 \pm 18(25)$ & 8 & NS \\
\hline Proteoglycan ( $\mathrm{mg} / \mathrm{g}$ tissue $)$ & $17.6 \pm 1.3(16)$ & $16.7 \pm 0.8(31)$ & -5 & NS \\
\hline
\end{tabular}

* Proteinase and inhibitor data are given as mean units/g wet tissue \pm SEM (number of specimens). There may be as many as three specimens per patient, corresponding to the three zones. ${ }^{\ddagger}$ Comparison is made between osteoarthritic and control values, $P$ was determined by Student's $t$ test. The three significant $P$ values all remain significant if the data are compared by number of patients (13 vs. 7$)$ instead of by the total number of specimens ( 37 vs. 16$)$.

Relative amounts of proteinases and inhibitor. The proportional increase in both acid and neutral proteinase activity in OA exceeded $130 \%$, whereas TIMP was elevated only $53 \%$ (Table III). It is important to estimate the relative amounts of enzyme and inhibitor; this was calculated as follows. First, published data for the molecular weight and specific activity against proteoglycan beads of acid metalloproteinase (8) and neutral metalloproteinase (28) were used to calculate the number of units of TIMP that would be required to titrate these two enzymes. TIMP was measured against a metalloproteinase of the rat uterus. This proteinase digests $30 \mathrm{mg}$ of Azocoll $/ \mathrm{min}$ per mg enzyme and its molecular weight is 20,000 (29). It could be calculated that $25 \mathrm{U}$ of TIMP found in $1 \mathrm{~g}$ of control cartilage (Table III) is equivalent to $1.1 \mu \mathrm{g}$ of TIMP, assuming a 1:1 stoichiometry of inhibitor to enzyme (30). Similar calculations show that $1.95 \mathrm{U}$ of acid metalloproteinase and $0.42 \mathrm{U}$ of neutral proteinase would require 15.2 and $6.8 \mathrm{U}$ of TIMP, respectively. Fig. 7 summarizes the main finding. There is sufficient TIMP to inhibit the two metalloproteinases in control samples, but in the medial compartment the amount is insufficient. Collagenase is not included in these calculations; the shortfall of TIMP in OA would be further magnified by its inclusion.

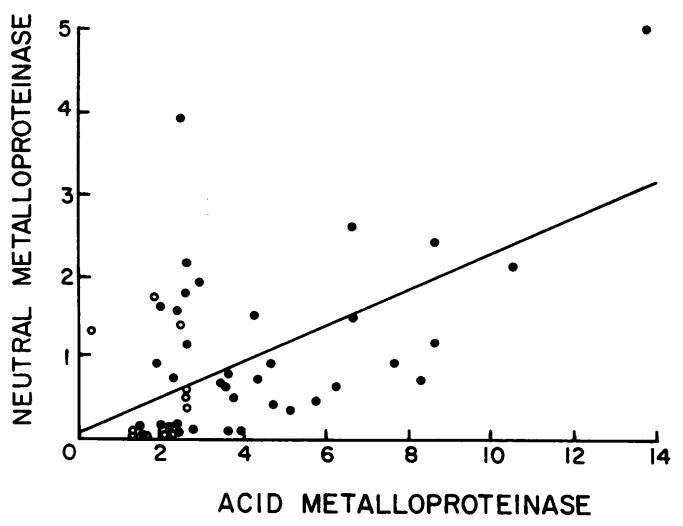

Figure 4. Correlation of total acid and neutral metalloproteinase activity. Units of total acid and neutral metalloproteinase per gram tissue found in human tibial plateau cartilage were determined as described in Methods. $r=0.505, P<0.001$. (O) Control; (๑) osteoarthritic cartilage.

\section{Discussion}

Validation of assay methods. The present advance in measuring proteinases and TIMP in cartilage was based on finding a good extraction method and ways in which to selectively destroy either enzymes or inhibitor, so that the one would not interfere in the assay of the other. Extraction with guanidine$\mathrm{HCl}$ proved to be superior to heat extraction methods found useful for other tissues $(19,31)$. The extracted activity is at least twice the activity detected by direct assay of homogenates, and there is good recovery of enzymes added back to the homogenates. However, it is still possible that a significant

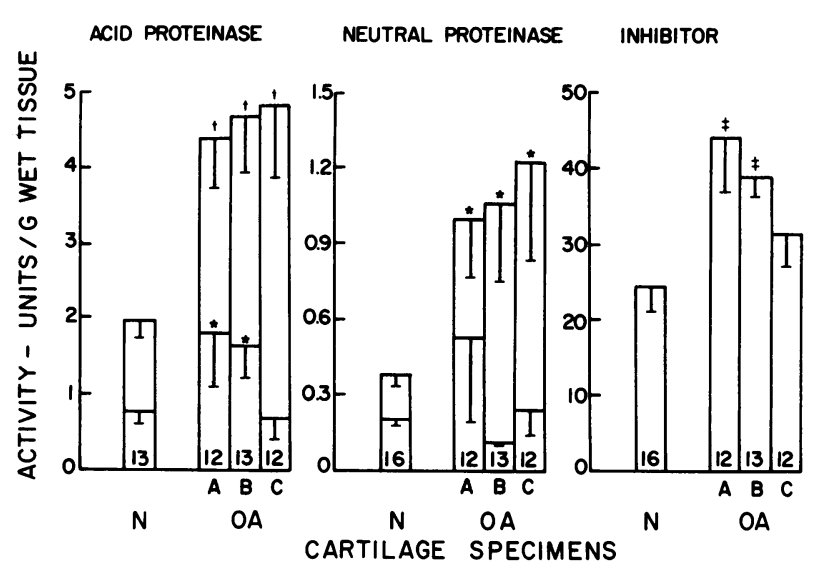

Figure 5. Regional variation of metalloproteinases and TIMP in osteoarthritis. Active metalloproteinase was determined without any additions to the assay, while total metalloproteinase contained $1 \mathrm{mM}$ APMA to activate the latent enzyme. Blanks were prepared by addition of $1 \mathrm{mM}$ 1,10-phenanthroline. Normal control values from two or three zones were pooled, while the osteoarthritic values were segregated into sites A, B, and C (Fig. 1). The central horizontal line in each bar indicates the mean value of active metalloproteinase activity while the top of the bar indicates the total metalloproteinase present in the region. The vertical lines within the bars indicate the standard error of the mean (SEM). The number of specimens is entered in the bottom of each bar. The Mankin scores \pm SEM for sites A-C in the osteoarthritic specimens were: $A, 6.9 \pm 0.7 ; B, 6.3 \pm 0.4$; and $C$, $3.8 \pm 0.5$. Statistically significant differences between control and osteoarthritic groups were determined with analysis of variance followed by the Tukey test. ${ }^{*} P<0.05, \uparrow P<0.02, \ddagger P<0.002$. 


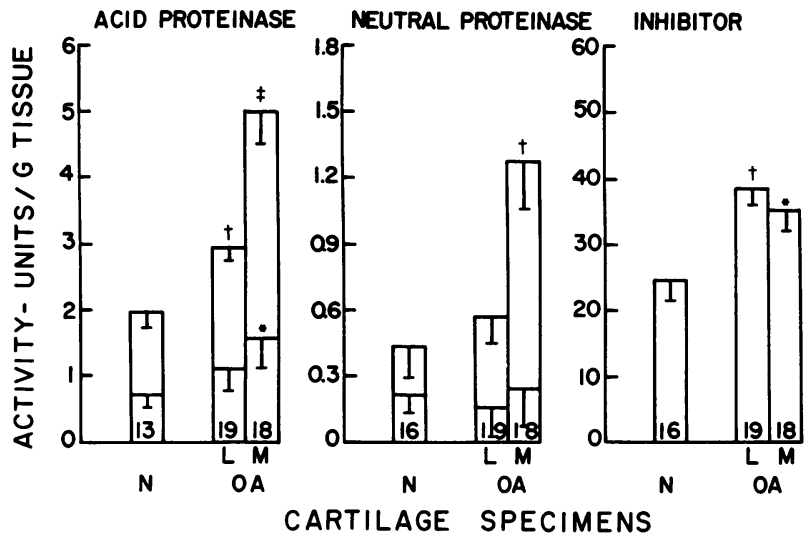

Figure 6. Compartmental variation of metalloproteinases and TIMP in osteoarthritis. Total and active metalloproteinase was assayed as described in Fig. 5. Normal $(N)$ control values were pooled, while the osteoarthritic values were segregated according to their original location on the medial $(M)$ or lateral $(L)$ plateau. The middle horizontal line in each bar indicates the mean value of active metalloproteinase activity; the top of the bar indicates the total metalloproteinase present. The vertical lines within the bars indicate the standard error of the mean (SEM). The number of specimens is entered in the bottom of each bar. Statistically significant differences between $O A$ and control groups were determined as described in Fig. $5 .{ }^{*} P<0.05, \dagger P$ $<0.01, \ddagger P<0.001$.

amount of active or latent enzyme remains unextracted and that the recoveries are not completely quantitative. It was known that TIMP was inactivated by reduction and alkylation $(13,17)$, but it had not been demonstrated that the cartilage proteinases were resistant to this treatment. It was also known that metalloproteases could be irreversibly denatured in the presence of EDTA; we have accelerated this process by heating, thereby taking advantage of the extreme heat stability of TIMP (13).

The methods have been further validated with respect to recovery of known amounts of added enzyme, linearity of assay with enzyme concentration, and recovery of active enzyme in extracts containing TIMP. The sensitivity of the proteoglycan bead and Azocoll substrates permits measurement of metalloproteinases and TIMP in as little as $50 \mathrm{mg}$ of wet cartilage. It is not necessary to separate enzyme and inhibitor before assay $(32,33)$. The amounts being assayed are typically $5-10 \mathrm{ng}$, or $\sim 50$ times less than amounts assayed by workers using culture medium sources of enzyme.

Although our earlier studies utilized endogenous substrate and did not take TIMP into account, they were basically sound. TIMP is inactivated by APMA (13); during the 3-5 h required to activate latent metalloproteases (Fig. 3) most of the TIMP was probably destroyed. Moreover, we showed $(9,10$, 34,35 ) that the proteoglycan levels in homogenates were not appreciably decreased in OA, so there were not large variations in substrate concentration. However, active metalloproteinase was underestimated $(7-10,14)$ and this may be attributed to reaction with TIMP during the long incubation period. In the present study as much as $30-40 \%$ of the total enzymes were in active form.

Proteinase and TIMP changes in $O A$. The present results are closely similar to the changes reported earlier: a $136 \%$ increase in acid metalloprotease and a $160 \%$ increase in the neutral activity may be compared to previous reports of $200 \%$ (10) and $600 \%$ (9), respectively, as measured in homogenates of tibial plateau. The tissues selected for the present study were not so severely diseased as the earlier tissues. The purpose of this was to show that the enzymes were elevated in earlier stages of OA and not just in end-stage disease. We have recently (36) identified the neutral proteinase as stromelysin (matrix metalloproteinase 3). It is important to note that the acid metalloprotease activity is about five times higher than that of stromelysin, suggesting that the former may play a more prominent role in OA. This is in contrast to the patella, where the two levels are more nearly equal (e.g., Fig. 2).

Enzyme distribution on the tibial plateau. The acid metalloproteinase was previously found to be elevated in lesions (zone A), but not in remote areas (zone C). In the present study it is elevated in all zones. However, the active form is elevated only in zones A and B. The neutral activity is elevated in all three zones, in agreement with previous findings $(9,34,35)$. In the present work the OA changes were found to be more extensive or severe in the medial compartment, including the Mankin score, carbon black retention and x-ray changes. Both of the metalloproteinases and TIMP were also higher in this compartment. One might argue that the lateral compartment is protected against gross cartilage decompensation, or alternatively, that the lesions are self-limiting and atrophic due to low weight-bearing. In comparing tissue from weight bearing and non-weight-bearing sites in control cartilage, we could see no significant differences. The lateral compartment may, therefore, provide suitable samples for studying early development of OA lesions. This would be of value since the usual surgical specimens from the medial compartment show extensive subchondral remodeling and fibrocartilage deposition, which may obscure the early biochemical and etiopathological events of interest.

We find that biochemical abnormalities occur in the lateral compartment, in spite of the mild histological changes. This is further supported by the significant elevation in metallopro-

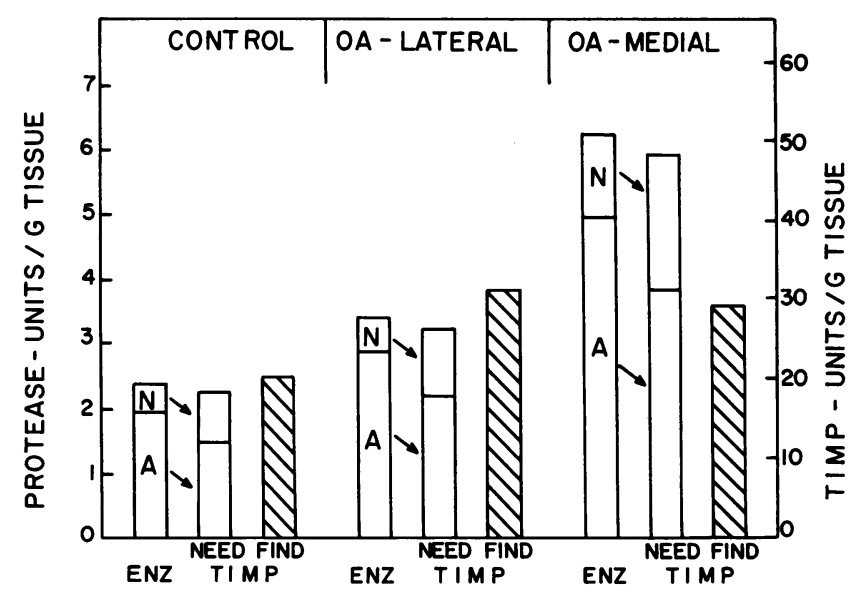

Figure 7. Comparison of metalloproteinase activity to its TIMP equivalent. The values for acid and neutral metalloproteinase and TIMP in the OA samples were divided according to their original location on the tibial plateau and compared with control samples. The first bar shows total neutral $(N)$ and acid $(A)$ metalloproteinase activity. The second bar shows the TIMP level needed to provide a 1:1 molar ratio. The third bar shows the amount of TIMP actually found. The number of samples in each group was the same as shown in Fig. 6. 
teinase levels seen in the Pond-Nuki dog model when there are low histological scores $(12,34,35)$. Brocklehurst et al. (37) suggest that nonfibrillated human OA knee cartilage may be normal by their criteria; they propose corrective osteotomy or unicompartmental joint replacement as rational options. The validity of this approach remains to be tested, but our data suggest that early OA changes may progress to include the nondecompensated compartment.

Regulation of proteinase activity. The present results indicate that metalloproteinases may be one of the factors responsible for the loss of matrix in OA. At least three regulatory mechanisms should be considered. First, the mechanical load may affect the cartilage integrity. Secondly, the enzymes are in latent form and require activation before they can attack the matrix. How this activation occurs is not known, but we find as much as $30 \%$ of the acid and $50 \%$ of the neutral enzyme in an active form in site $\mathrm{A}$. The third factor is the protein inhibitor of metalloproteases, originally noted by Killackey et al. (38) and characterized by us as TIMP (13) based on identity of properties to those described by Cawston et al. (30) and others (39-41).

The present data suggest a close balance between activities of metalloproteases and levels of TIMP in normal cartilage. In $\mathrm{OA}$, the protease activities rise proportionally higher than the levels of TIMP, leading to a presumptive excess of proteinase. This result matches closely the conclusion we reached in our earlier study of patellar tissue (14). This hypothesis would offer a reasonable explanation of why tissue damage becomes excessive in OA, whereas in normal tissues the same enzymes probably account for matrix turnover. However, the present findings must be viewed with some caution since they include several simplifying assumptions. For example, at any instant only part of the total enzyme is in an active state. On the other hand, it is also assumed that the enzymes and inhibitor are freely accessible to one another in the same compartment of the extracellular matrix. In spite of these possible under- or overestimates, one must recognize the fact that the levels of enzymes and inhibitor are closely matched and that there is not a vast reservoir of proteinase inhibitor as, for example, in the blood. Any factor that upsets this balance may contribute to the development of OA.

\section{Acknowledgments}

The authors would like to express their appreciation for the expert technical assistance provided by Ms. Carolyn Taplin and Ms. Marie Selzer. The authors also wish to thank Geneva Jackson for her excellent secretarial assistance.

This study was supported by National Institutes of Health grants AR-16940 and AR-08662 and by the Medical Research Council of Canada. Dr. Dean was a postdoctoral Fellow of the Arthritis Foundation.

\section{References}

1. Lawrence, J. S., J. M. Bremener, and F. Beir. 1966. Osteoarthrosis: prevalence in the population and relationship between symptoms and x-ray changes. Ann. Rheum. Dis. 25:1-24.

2. Howell, D. S. 1986. Pathogenesis of osteoarthritis. Am. J. Med. 80(Suppl. 4B):24-28.

3. Mankin, H. J., H. Dorfman, L. Lippiello, and A. Zarins. 1971. Biochemical and metabolic abnormalities in articular cartilage from osteoarthritic human hips. II. Correlation of morphology with biochemical and metabolic data. J. Bone Jt. Surg. Am. Vol. 53:523-537.
4. Ehrlich, M. G. 1985. Degradative enzyme systems in osteoarthritic cartilage. J. Orthoped. Res. 3:170-184.

5. Sapolsky, A. I., R. D. Altman, J. F. Woessner, Jr., and D. S. Howell. 1973. The action of cathepsin D in human articular cartilage on proteoglycans. J. Clin. Invest. 56:624-633.

6. Sapolsky, A. I., H. Keiser, D. S. Howell, and J. F. Woessner, Jr. 1976. Metalloproteases of human articular cartilage that digest cartilage proteoglycan at neutral and acid pH. J. Clin. Invest. 58:10301041.

7. Woessner, J. F. Jr., and M. G. Selzer. 1984. Two latent metalloproteinases of human articular cartilage that digest proteoglycan. $J$. Biol. Chem. 259:3633-3638.

8. Azzo, W., and J. F. Woessner, Jr. 1986. Purification and characterization of an acid metalloproteinase from human articular cartilage. J. Biol. Chem. 261:5434-5441.

9. Martel-Pelletier, J., J.-P. Pelletier, J. M. Cloutier, D. S. Howell, L. Ghandur-Mnaymneh, and J. F. Woessner, Jr. 1984. Neutral proteases capable of proteoglycan digesting activity in osteoarthritic and normal human articular cartilage. Arthritis Rheum. 27:305-312.

10. Pelletier, J.-P., J. Martel-Pelletier, J. M. Cloutier, and J. F. Woessner, Jr. 1987. Proteoglycan-degrading acid metalloproteinase activity in human osteoarthritic cartilage and the effect of intraarticular steroid injections. Arthritis Rheum. 30:541-548.

11. Pelletier, J.-P., J. Martel-Pelletier, D. S. Howell, L. GhandurMnaymneh, J. E. Enis, and J. F. Woessner, Jr. 1983. Collagenase and collagenolytic activity in human osteoarthritic cartilage. Arthritis Rheum. 26:63-68.

12. Pelletier, J.-P., J. Martel-Pelletier, R. D. Altman, L. GhandurMnaymneh, D. S. Howell, and J. F. Woessner, Jr. 1983. Collagenolytic activity and collagen matrix breakdown of the articular cartilage in Pond-Nuki dog model of osteoarthritis. Arthritis Rheum. 26:866-874.

13. Dean, D. D., and J. F. Woessner, Jr. 1984. Extracts of human articular cartilage contain an inhibitor of tissue metalloproteinases. Biochem. J. 218:277-280.

14. Dean, D. D., W. Azzo, J. Martel-Pelletier, J.-P. Pelletier, and J. F. Woessner, Jr. 1987. Levels of metalloproteinases and tissue inhibitor of metalloproteinases in human osteoarthritic cartilage. J. Rheumatol. 14(Suppl):43-44.

15. Meachim, G. 1972. Light microscopy of India ink preparations of fibrillated cartilage. Ann. Rheum. Dis. 31:457-464.

16. Nagase, H., and J. F. Woessner, Jr. 1980. An improved assay for proteases and polysaccharidases employing a cartilage proteoglycan substrate entrapped in polyacrylamide particles. Anal. Biochem. 107:385-391.

17. Dean, D. D., T. E. Curry, W. J. LeMaire, and J. F. Woessner, Jr. 1987. Determination of metalloproteinase activity after selective destruction of tissue inhibitor of metalloproteinases. Trans. 33rd Ann. Meet. Orthopaed. Res. Soc. 12:248.

18. Rajabi, M., D. D. Dean, and J. F. Woessner, Jr. 1987. High levels of serum collagenase in premature labor-A potential biochemical marker. Obstet. Gynecol. 69:179-186.

19. Sellers, A., and J. F. Woessner, Jr. 1980. The extraction of a neutral metalloproteinase from the involuting rat uterus, and its action on cartilage proteoglycan. Biochem. J. 189:521-531.

20. Oegema, T. R., B. J. Carpenter, and R. C. Thompson. 1984. Fluorometric determination of DNA in cartilage of various species. $J$. Orthoped. Res. 1:345-351.

21. LaBarca, C., and K. Paigen. 1980. A simple, rapid, and sensitive DNA assay procedure. Anal. Biochem. 102:344-352.

22. Bradford, M. M. 1976. A rapid and sensitive method for the quantitation of microgram quantities of protein utilizing the principle of protein-dye binding. Anal. Biochem. 72:248-254.

23. Farndale, R. W., C. A. Sayers, and A. J. Barrett. 1982. A direct spectrophotometric microassay for sulfated glycosaminoglycans in cartilage cultures. Connect. Tiss. Res. 9:247-248.

24. Zar, J. H. 1984. Biostatistical Analysis. 2nd edition, Prentice Hall, Inc., Englewood Cliffs, NJ. 306-327. 
25. Weeks, J. G., J. Halme, and J. F. Woessner, Jr. 1976. Extraction of collagenase from the involuting rat uterus. Biochim. Biophys. Acta. 445:205-214.

26. Kellgren, J. H., and J. S. Lawrence. 1963. The Epidemiology of Chronic Rheumatism: Atlas of Standard Radiographs. Vol. 2. Blackwell Scientific Publications, Oxford.

27. Altman, R. D., E. Asch, D. Bloch, G. Bole, D. Borenstein, K. Brandt, W. Christy, T. D. Cooke, R. Greenwald, M. Hochberg, D. Howell, D. Kaplan, W. Koopman, S. Longley, III, H. Mankin, D. J. McShane, T. Medsger, Jr., R. Meenan, W. Mikkelsen, R. Moskowitz, W. Murphy, B. Rothschild, M. Segal, L. Sokoloff, and F. Wolfe. 1986. Development of criteria for the classification and reporting of osteoarthritis: classification of osteoarthritis of the knee. Arthritis Rheum. 29:1039-1049.

28. Okada, Y., H. Nagase, and E. D. Harris, Jr. 1986. A metalloproteinase from human rheumatoid synovial fibroblasts that digests connective tissue matrix components. Purification and characterization. J. Biol. Chem. 261:14245-14255.

29. Woessner, J. F., Jr., and C. J. Taplin. 1989. Purification and properties of a small latent matrix metalloproteinase of the rat uterus. J. Biol. Chem. 263:16918-16925.

30. Cawston, T. E., G. Murphy, E. Mercer, W. A. Galloway, B. L. Hazelman, and J. J. Reynolds. 1983. The interaction of purified rabbit bone collagenase with purified rabbit bone metalloproteinase inhibitor. Biochem. J. 211:313-318.

31. Curry, T. E., D. D. Dean, J. F. Woessner, Jr., and W. J. LeMaire. 1985. The extraction of a tissue collagenase associated with ovulation in the rat. Biol. Reprod. 33:981-991.

32. Morales, T. I., K. E. Kuettner, D. S. Howell, and J. F. Woessner, Jr. 1983. Characterization of the metalloproteinase inhibitor produced by bovine articular chondrocyte cultures. Biochim. Biophys. Acta. 760:221-229.

33. Herron, G. S., M. J. Banda, E. J. Clark, J. Gavrilovic, and Z.
Werb. 1986. Secretion of metalloproteinases by stimulated capillary endothelial cells. II. Expression of collagenase and stromelysin activities is regulated by endogenous inhibitors. J. Biol. Chem. 261:28142818.

34. Pelletier, J.-P., and J. Martel-Pelletier. 1985. Neutral proteoglycan degrading protease activity in the early cartilage lesions of experimental osteoarthritis. Trans. 31st Annu. Meet. Orthopaed. Res. Soc. 10:128.

35. Pelletier, J.-P., and J. Martel-Pelletier. 1985. Cartilage degradation by neutral proteoglycanases in experimental osteoarthritis: Suppression by steroids. Arthritis Rheum. 28:1393-1401.

36. Gunja-Smith, Z., H. Nagase, and J. F. Woessner, Jr. 1989. Purification of the neutral proteoglycan-degrading metalloproteinase from human articular cartilage tissue and its identification as stromelysin matrix metalloproteinase-3. Biochem. J. 258:115-119.

37. Brocklehurst, R., M. T. Bayliss, A. Maroudas, H. L. Coysh, M. A. R. Freeman, P. A. Revell, and S. Y. Ali. 1984. The composition of normal and osteoarthritic cartilage from human knee joints. J. Bone Jt. Surg. Am. Vol. 66:95-106.

38. Killackey, J., P. J. Roughley, and J. S. Mort. 1983. Proteinase inhibitors of human articular cartilage. Collagen Relat. Res. 3:419430.

39. Carmichael, D. F., A. Sommer, R. C. Thompson, D. C. Anderson, C. G. Smith, H. G. Welgus, and G. P. Stricklin. 1986. Primary structure and cDNA cloning of human fibroblast collagenase inhibitor. Proc. Natl. Acad. Sci. USA. 83:2407-2411.

40. Docherty, A. J. P., A. Lyons, B. J. Smith, E. M. Wright, P. E. Stephens, T. J. R. Harris, G. Murphy, and J. J. Reynolds. 1985. Sequence of human tissue inhibitor of metalloproteinases and its identity to erythroid-potentiating activity. Nature (Lond.). 318:66-69.

41. Hembry, R. M., G. Murphy, and J. J. Reynolds. 1985. Immunolocalization of tissue inhibitor of metalloproteinases (TIMP) in human cells. Characterization and use of a specific antiserum. J. Cell Sci. 73:105-119. 